\title{
TEXTILE PATTERNS BASED ON ANCIENT EGYPTIAN ORNAMENTS
}

\author{
EISayed A. EINashar ${ }^{1}$, Zlatin Zlatev², Julieta llieva ${ }^{2}$ \\ ${ }^{1}$ Faculty of Specific Education, Kafrelsheikh University, Egypt \\ El-Geish Street, 33516 Kafrelsheikh City, Egypt, e-mail: smartex@kfs.edu.eg \\ ${ }^{2}$ Faculty of Technics and Technologies, Trakia University, Bulgaria Graf Ignatiev 38, 8602 \\ Yambol, Bulgaria e-mail: zlatin.zlatev@trakia-uni.bg, zhulieta.ilieva@trakia-uni.bg
}

\begin{abstract}
A developed digital collection of textile patterns is presented lin the report. As objects in this collection designed modern textile prints developed on the basis of elements of ancient Egyptian costume are included. Software tools are developed to obtain colors, shapes and descriptions of the used ancient Egyptian elements. The resulting elements are in vector format, and can be used in CAD systems and spreadsheets. Descriptions of these motifs can be used for comparison with such elements from other national costumes.
\end{abstract}

Keywords: Digital collection, Ancient Egypt, Ornaments, Colors, Image processing, Textile Patterns.

\section{INTRODUCTION}

Ancient Egypt has left a certain imprint on the art of Mesopotamia. Various geometric shapes decorate the walls of tombs, sarcophaguses, household items, clothing and other textiles. The costume of ancient Egypt and its decorative elements inspire designers in the design of clothing and textiles [9]. More than one are the examples of the use of these ancient elements.

The actuality of the theme of the conceptual dimensions of the historical costume of ancient Egypt, its ornaments and colors, as well as its implication in modern fashion is the fact that seek sources of inspiration of the founders of today's fashion brands and fashion lines closer or more distant historical horizons, but fashion never returned as something frozen.

Famous fashion designers are inspired by the long past ages, it is recognized by many as fact, but the logic of the emergence of new forms and silhouettes other, not as it is formed during the initial generation [5].

To preserve the authenticity of ornaments and colors of ancient Egypt and the use of decorative elements on clothing to create patterns, decoration of clothes [2, 3], at contemporary stage are applied analytical techniques and image processing [4].

The resulting colors, shapes and metadata for elements of ancient Egypt can be used to create a digital collection, which consists of the following main components [1]:

$>$ Collection - organized groups of objects;

$>$ Objects - digitized materials;

$>$ Metadata - information about objects and collections of them;

$>$ Initiative for development and use - programs and projects for creating, organizing and managing of the collections.

A digital collection have to consists digital objects that are selected and organized to facilitate their discovery, access, and use. Objects, metadata, and the user interface together create the user experience of a collection.

The aim of this report is to develop software tools to obtain colors and shapes of ancient Egyptian costume and based on them to design modern textile prints by creating a digital collection of them.

IRTTE Vol. 4, No. 2, 2016 ISSN 1314-8788 (print), ISSN 1314-8796 (online), doi: 10.15547/artte.2016.02.002 


\section{IRTTIE}

Ipplied Resseirthes in Technics, Technologies and Bductition Journal of the Faculty of Technics and Technologies, Trakia University https://sites.google.com/a/trakia-uni.bg/artte/

\section{SOFTWARE TOOLS FOR OBTAINING SHAPES AND COLORS OF DECORATIVE ELEMENTS FROM ANCIENT EGYPT}

For the purpose of this work was created a program in Matlab environment [7] to extract contours, radius-vector functions and color palettes from images. As a result the developed algorithm allows the designer to choose shapes and colors, and to selecting those that meet the needs of a specific project. Also results from this algorithm can be used for automatic comparison between elements of clothes and fabrics of different nationalities.

\subsection{Extraction of contour of the element in the image}

The algorithm to obtain the contour of the element in the image is performed in the following sequence (Figure 1):

$>$ Loading of the original image;

> Conversion from RGB to Lab color model. Used is only the L component;

$>$ Binarization of the image;

$>$ Filtering of the image;

Removing of small objects as points and parts of background;

> Determination the contour of the object by function "imcontour";

$>$ Recording the coordinates of the contour in file.

Using the channel Lightness is suitable for practical purposes because working with this channel does not differ significantly from tone correction of the image like transformation into gray, but unlike aggregated curves as in RGB or CMYK color models that are also hardwaredependent, $\mathrm{L}_{\mathrm{Lab}}$ component does not affect the color saturation, and account for changes in brightness.

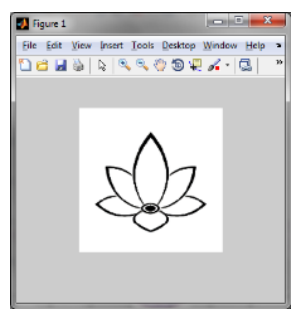

a) original image

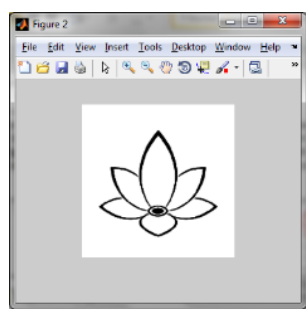

b) L color component

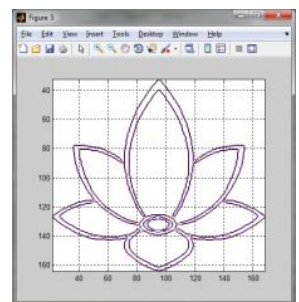

c) "imcontour" function

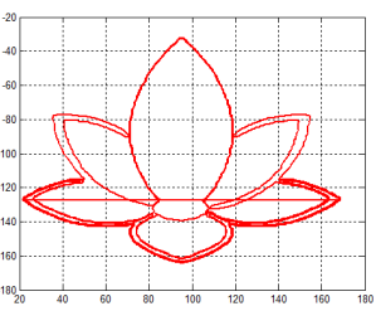

d) contour of the element

Figure 1.

Stages of the algorithm for extracting of contours from decorative element

The obtained contours in vector format can be processed in CAD systems such as AutoCAD, as well as in spreadsheets such as MS Excel (figure 2). The extraction and representation in these software products is made as described in [11]. 


\section{ARTTL $Y$}

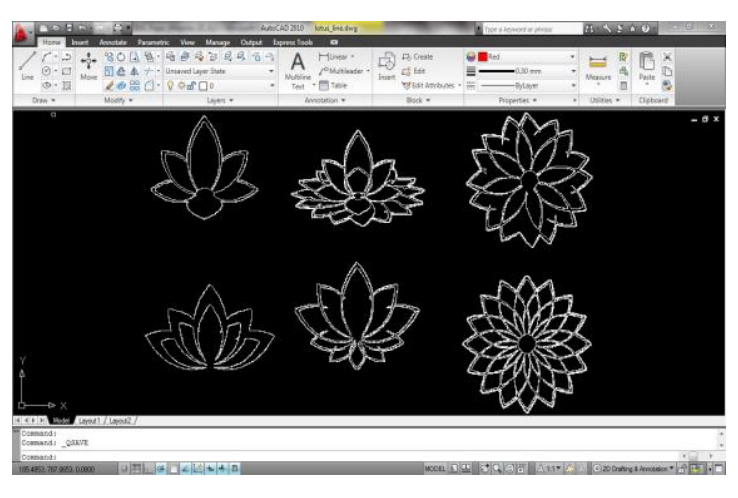

a) in AutoCAD
Ipplied Researrorches in Technics, Technologies and Mducation

Journal of the Faculty of Technics and Technologies, Trakia University https://sites.google.com/a/trakia-uni.bg/artte/

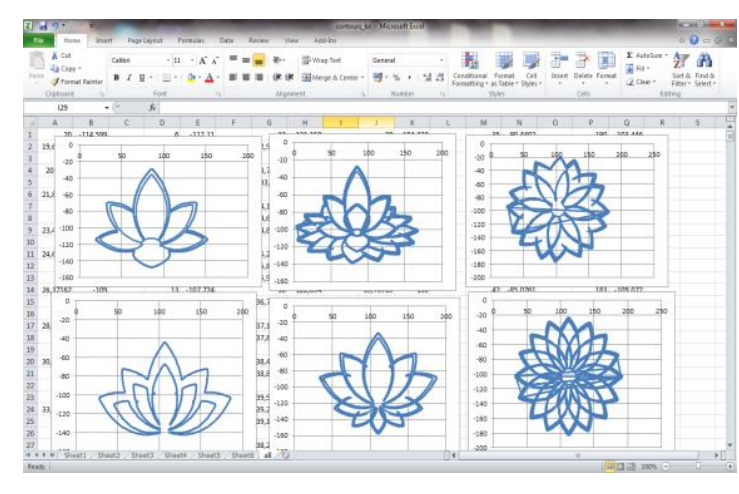

b) in MS Excel

Figure 2.

Extracted Lotus ornaments represented in AutoCAD and MS Excel

\subsection{Descriptions by radius vector function}

It is used a radius-vector function [8], which reflects the dependence of the magnitude of the vector spent by particular point on the inside of the object (centroid) to any point on the border of its inclination relative to a positive X-axis of the coordinate system. The beginning of this vector is usually accepted some typical for the object point, as in this case, the center of mass of the arrangement at issue. When the 0 to $360^{\circ}$, then the vector completely bypassing the outside used as the description of the shape of the object. Figure 3 presents the stages upon receipt of the radius-vector function of decorative element.

The same algorithm for determination the contour of an object in an image is used to obtain the radius-vector function. Features have been added for finding the center of mass of the object (centroid) and for calculation of radius of this center to all points on the contour. The resulting characteristics finally are recorded in a file.

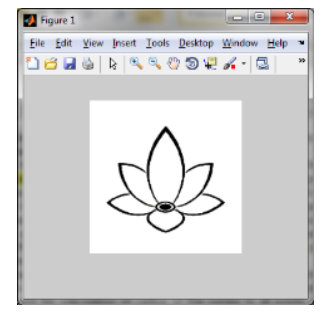

a) original image

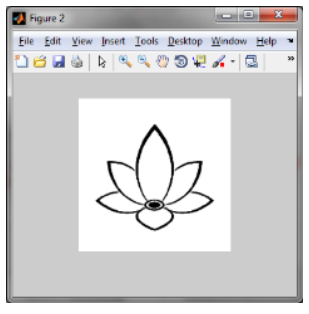

b) L color component

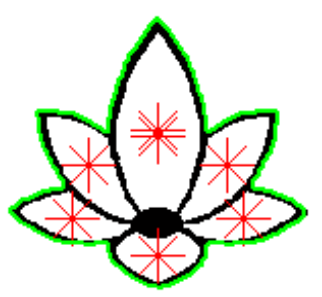

c) centroids of all leaves

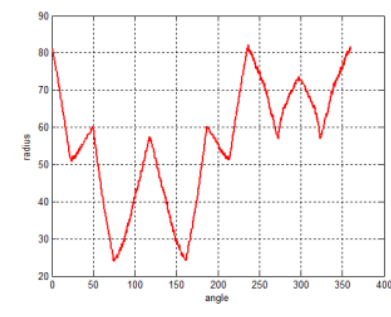

d) radius-vector function

Figure 3.

Stages of the algorithm for obtaining of radius-vector function

An electronic catalog is made with the coordinates of the contours of ancient Egyptian motifs consisting of 50 motifs. The catalog is supplemented with radius-vector functions. The obtained contours can be used to create textile prints and the radius vector function in the comparison with Egyptian motifs with those of other nationalities to detect similarities between them.

IRITIE Vol. 4, No. 2, 2016 ISSN 1314-8788 (print), ISSN 1314-8796 (online), doi: 10.15547/artte.2016.02.002 


\section{IRTTE}

Ipplied Researlohes in Technics, Technologies and Bductition Journal of the Faculty of Technics and Technologies, Trakia University https://sites.google.com/a/trakia-uni.bg/artte/

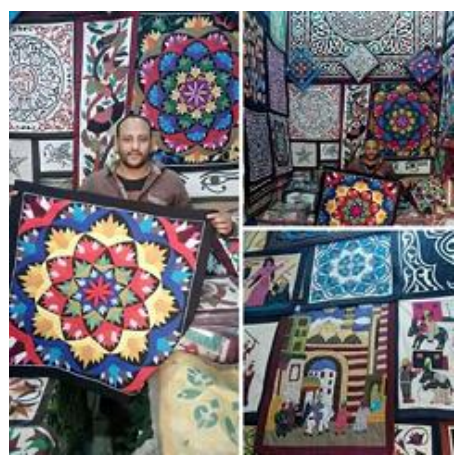

a) original image

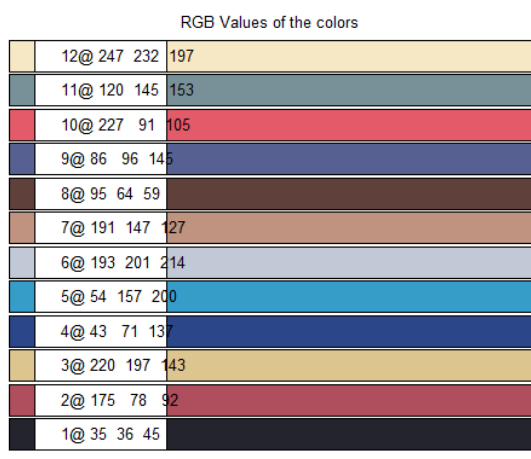

b) extracted twelve colors

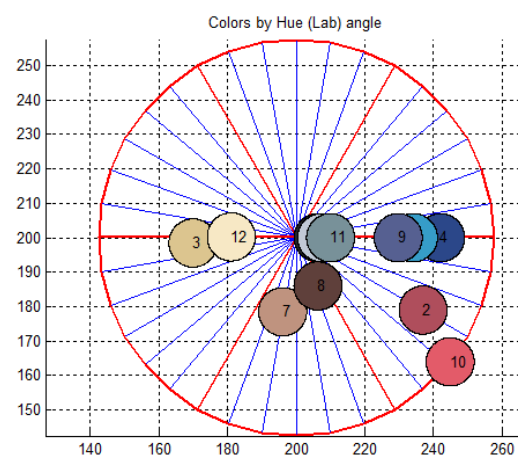

c) Lab color wheel

Figure 4.

Example of extraction colors from image

\subsection{Obtaining of colors of the image}

The algorithm presented in [12] is used to obtain the colors of images. The work of the algorithm is presented in Figure 4. The original image and this reduced to seven colors. The rectangles filled with the resultant colors are numbered. This numbering is used to indicate the RGB values in the range $0 \div 255$ for each color component. The colors are represented in Lab color wheel instead of HSV, as in the original algorithm. This algorithm can extract up to 65635 colors from image.

\section{DIGITAL COLLECTION FROM ELEMENTS OF THE ANCIENT EGYPTIAN COSTUME}

As a basic element for the development of patterns was used the lotus. It is one of the most common elements ancient Egyptian lotus, which is the sacred flower at ancient Egyptians, a symbol of the sun, beauty and purity. This form permeates all Egyptian art, stemming from the lotus-shaped, temple columns and ending with miniature toilets vessels and jewelery ornaments. From ancient times the lotus has been associated with the supreme power as a symbol of Upper Egypt, and scepter of the Egyptian pharaohs resemble at lotus flower on a long stem. The most beautiful ancient Egyptian drawings are entered in linear ornaments lotus buds and flowers. Egyptians also used them many different colors, structured in accordance with human psychology. A large number of bright, dark and black contrasting elements. The lotus may be in a different color, issuing different symbolism. The most common colors of the lotus are white, red, blue, pink and purple $[6,10]$.

On figure 5 are presented ornaments, extracted with the proposed above algorithms. Figure 6 represents the color solutions with the extracted ornaments. 


\section{ARTTIE}

Ipplied Researr ches in Technics, Technologies and Bducation Journal of the Faculty of Technics and Technologies, Trakia University https://sites.google.com/a/trakia-uni.bg/artte/
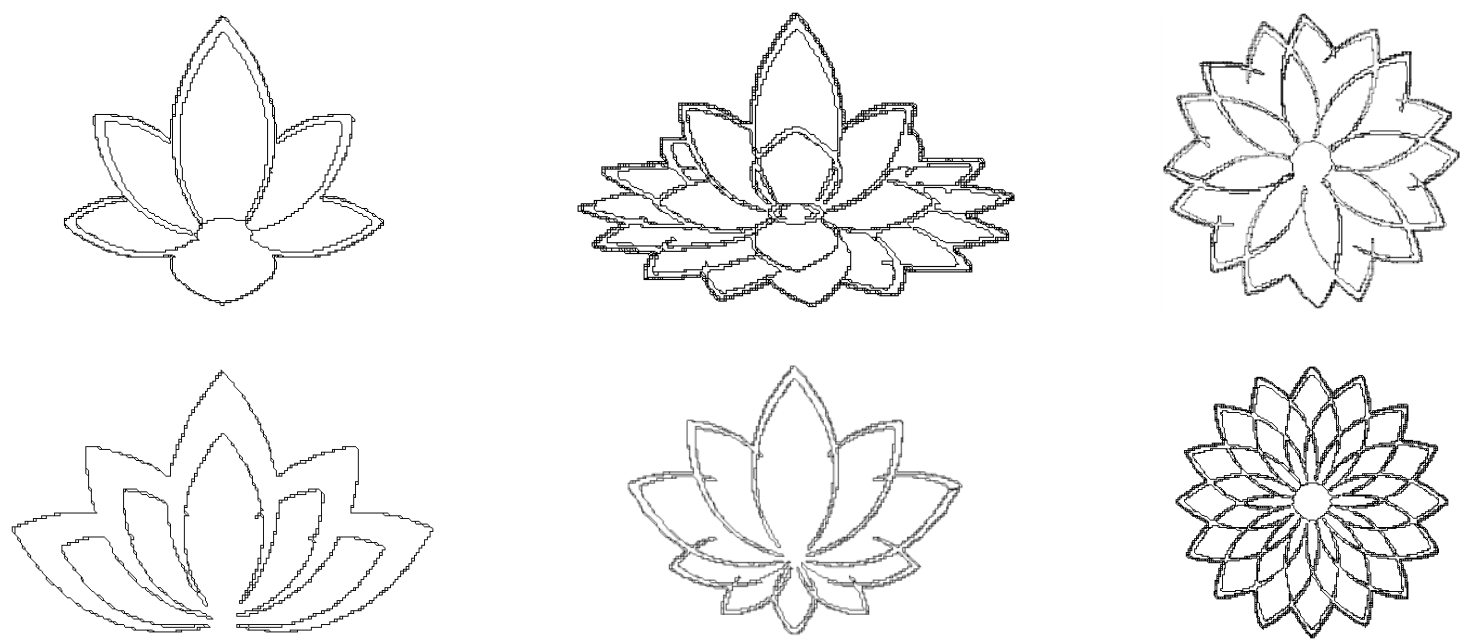

Figure 5.

Stylized lotus -6 ornaments

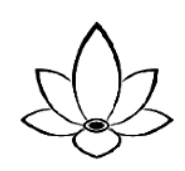

Lotus 1

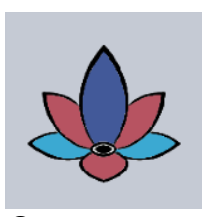

Ornament 1.1

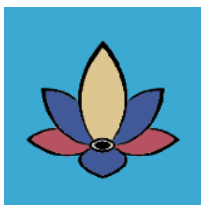

Ornament 1.2

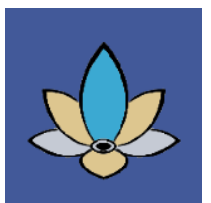

Ornament 1.3

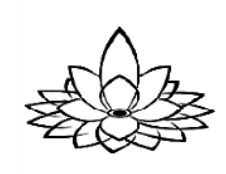

Lotus 2
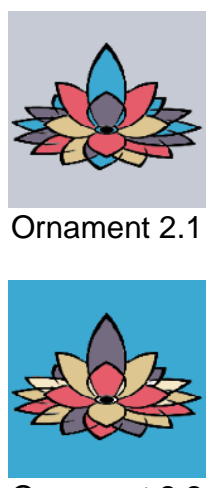

Ornament 2.2

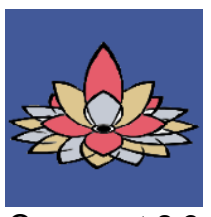

Ornament 2.3

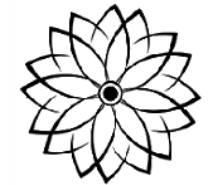

Lotus 3

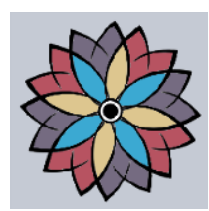

Ornament 3.1

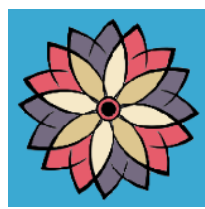

Ornament 3.2

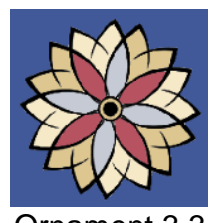

Ornament 3.3

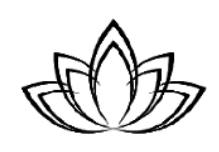

Lotus 4
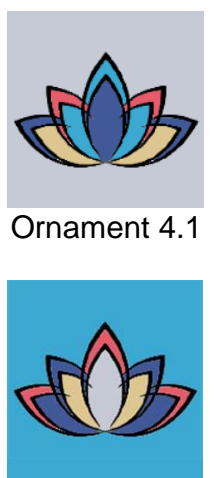

Ornament 4.2

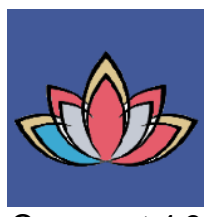

Ornament 4.3

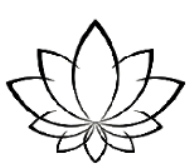

Lotus 5

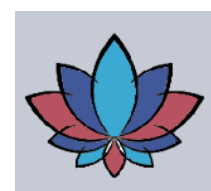

Ornament 5.1

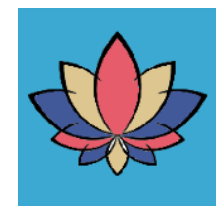

Ornament 5.2

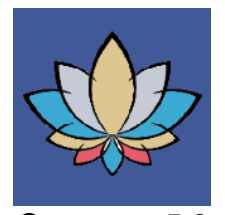

Ornament 5.3

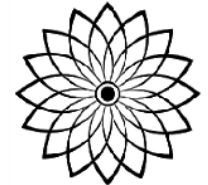

Lotus 6
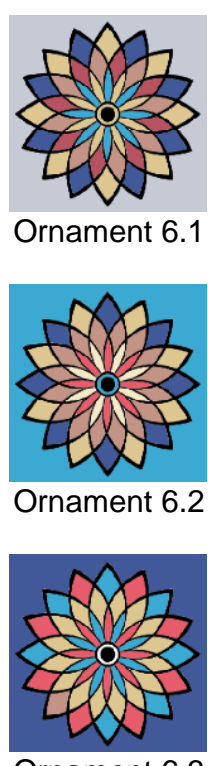

Ornament 6.3

Figure 6.

18 Color solutions for 6 ornaments with lotus

IRTIIE Vol. 4, No. 2, 2016 ISSN 1314-8788 (print), ISSN 1314-8796 (online), doi: 10.15547/artte.2016.02.002 


\section{IRTTIE}

Ipplied Researlores in Technics, Technologies ind Buncition Journal of the Faculty of Technics and Technologies, Trakia University https://sites.google.com/a/trakia-uni.bg/artte/

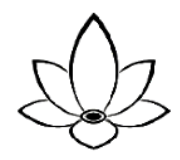

Lotus 1
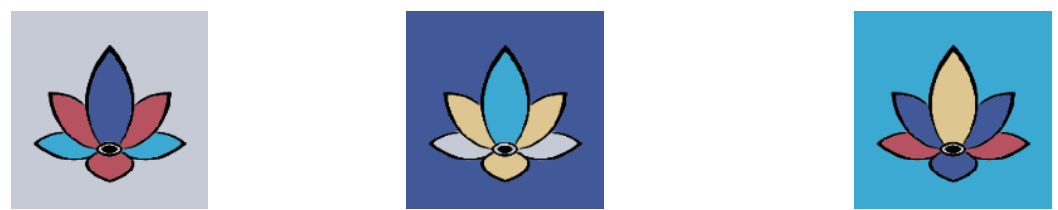
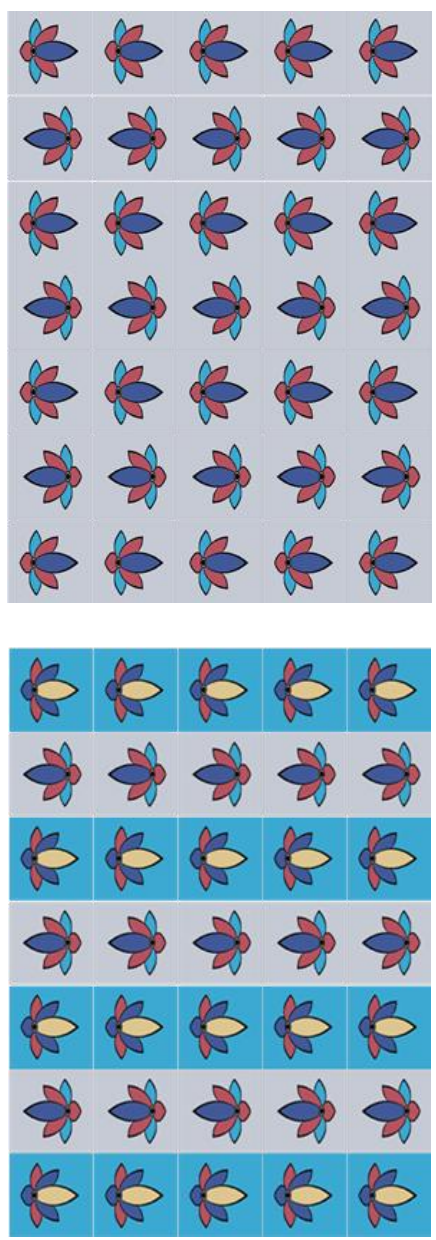

de de de de de

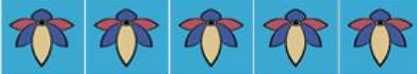

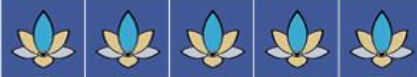
\& 8 \& de de de de de $8 \% 8 \%$ if de de de de
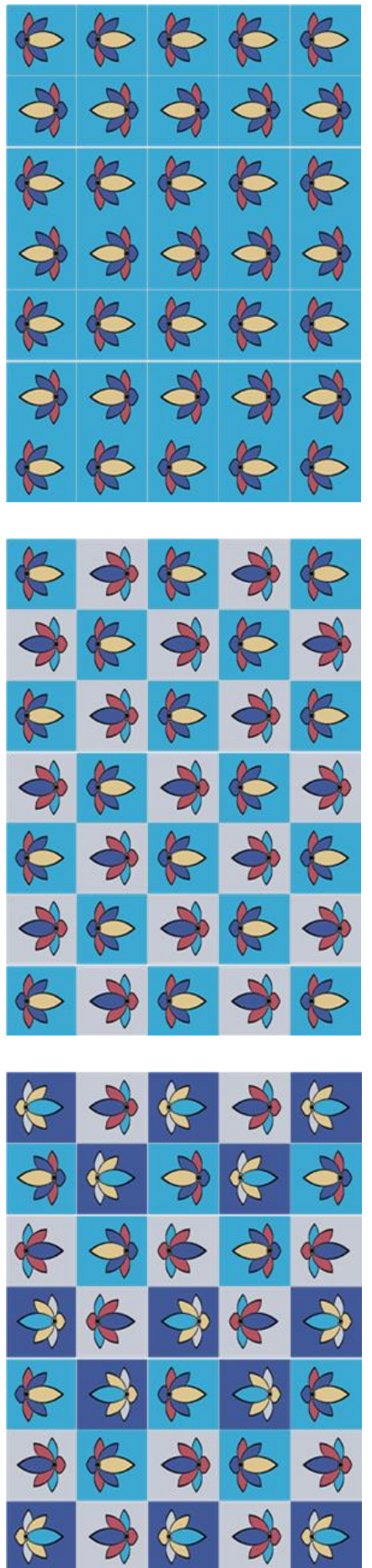

Figure 7. Projects of prints with stylized lotus 1

IRTIIE Vol. 4, No. 2, 2016 ISSN 1314-8788 (print), ISSN 1314-8796 (online), doi: 10.15547/artte.2016.02.002 


\section{IRTTL $Y$}

Ipplied Resserrrches in Technics, Technologies ind Bduration Journal of the Faculty of Technics and Technologies, Trakia University https://sites.google.com/a/trakia-uni.bg/artte/

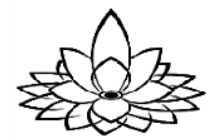

Lotus 2
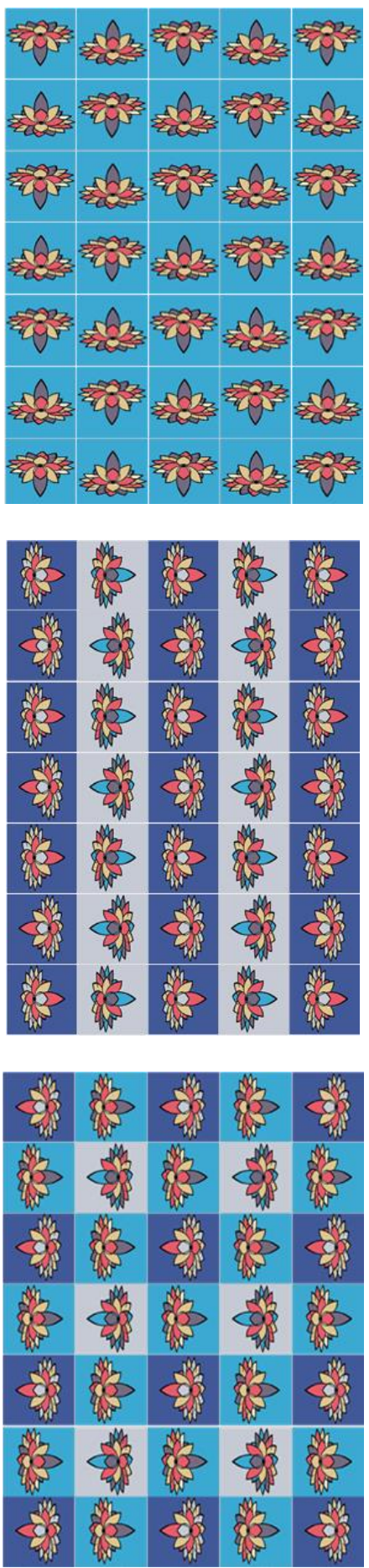
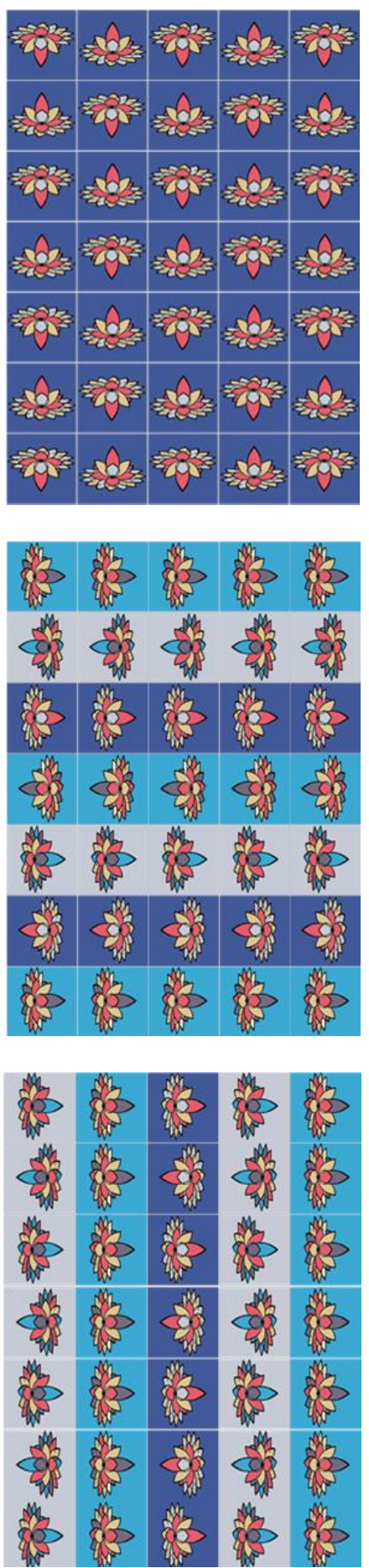

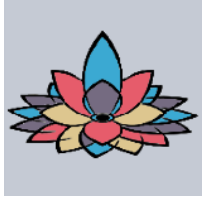

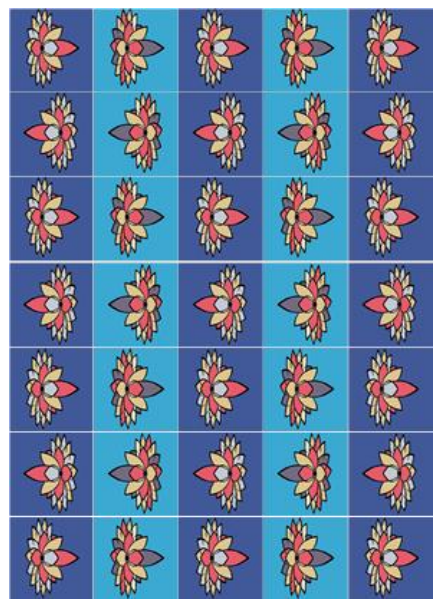

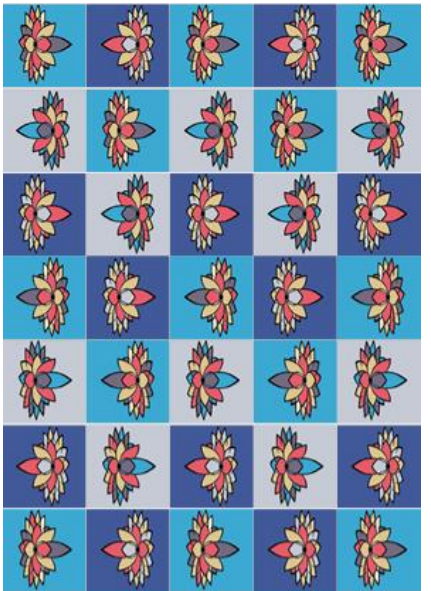

Figure 8. Projects of prints with stylized lotus 2

IRTIIE Vol. 4, No. 2, 2016 ISSN 1314-8788 (print), ISSN 1314-8796 (online), doi: 10.15547/artte.2016.02.002 


\section{IRTITE $\vee$}

Ipplied Resseirlches in Technicis, Technologies and Bductition Journal of the Faculty of Technics and Technologies, Trakia University https://sites.google.com/a/trakia-uni.bg/artte/

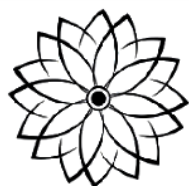

Lotus 3

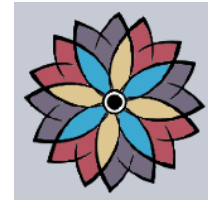

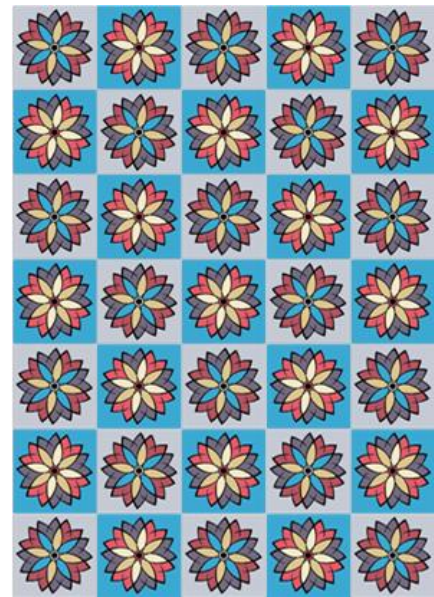

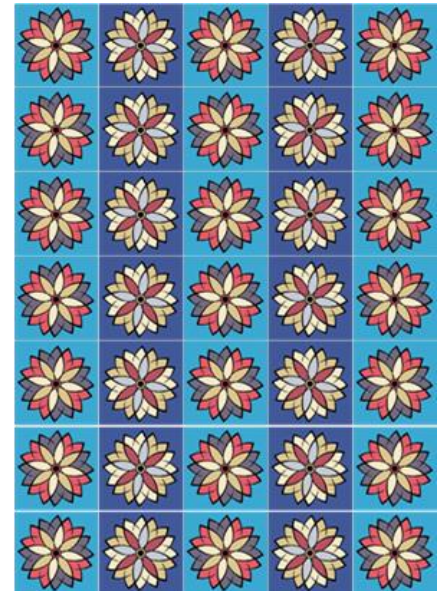

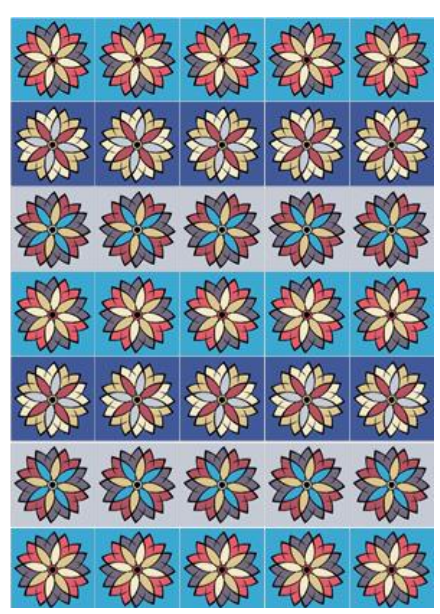

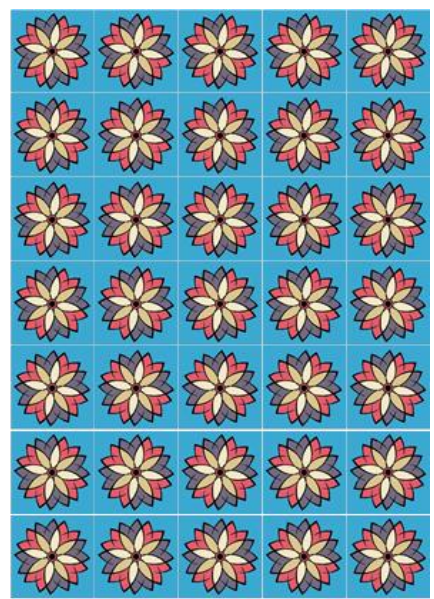

13 13

地地,

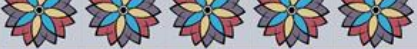

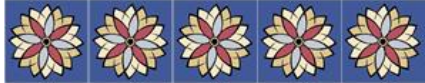

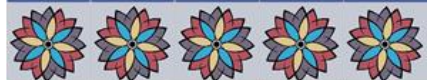

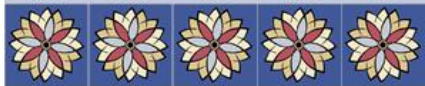

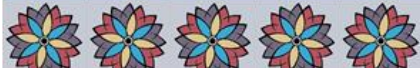
( $)$

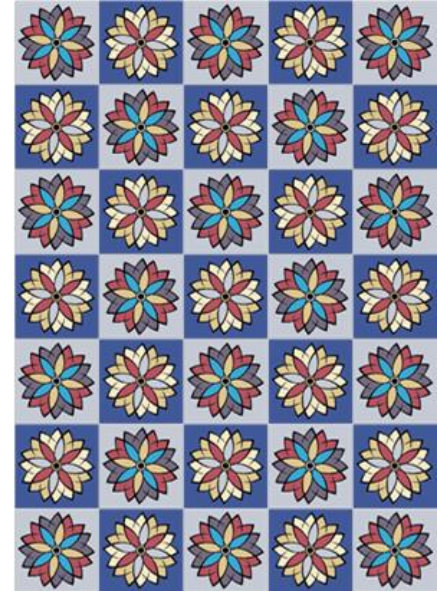

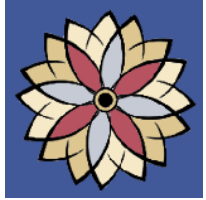

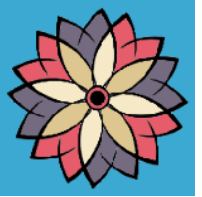

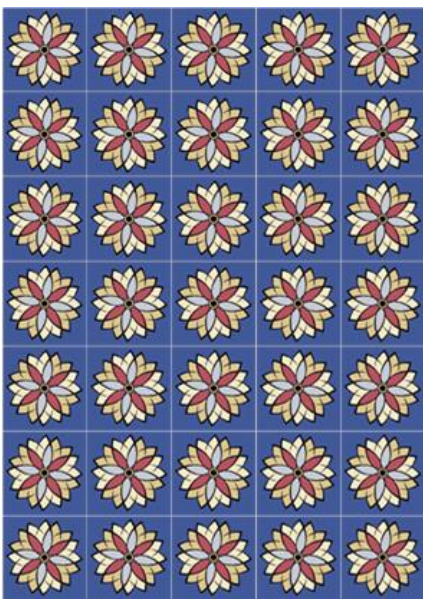
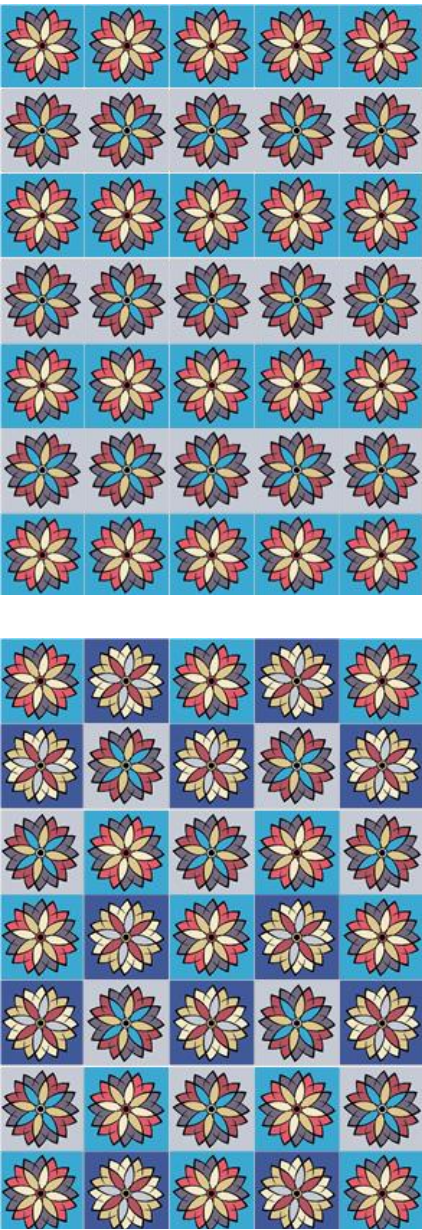

Figure 9. Projects of prints with stylized lotus 3

IRTTIE Vol. 4, No. 2, 2016 ISSN 1314-8788 (print), ISSN 1314-8796 (online), doi: 10.15547/artte.2016.02.002 


\section{IRTITE $Y$ P}
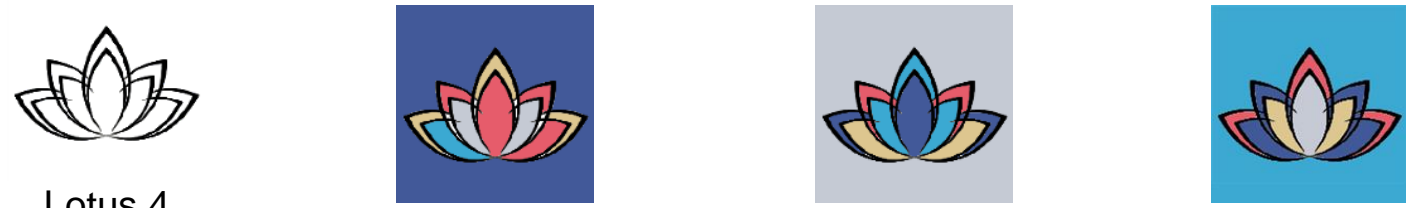

Lotus 4
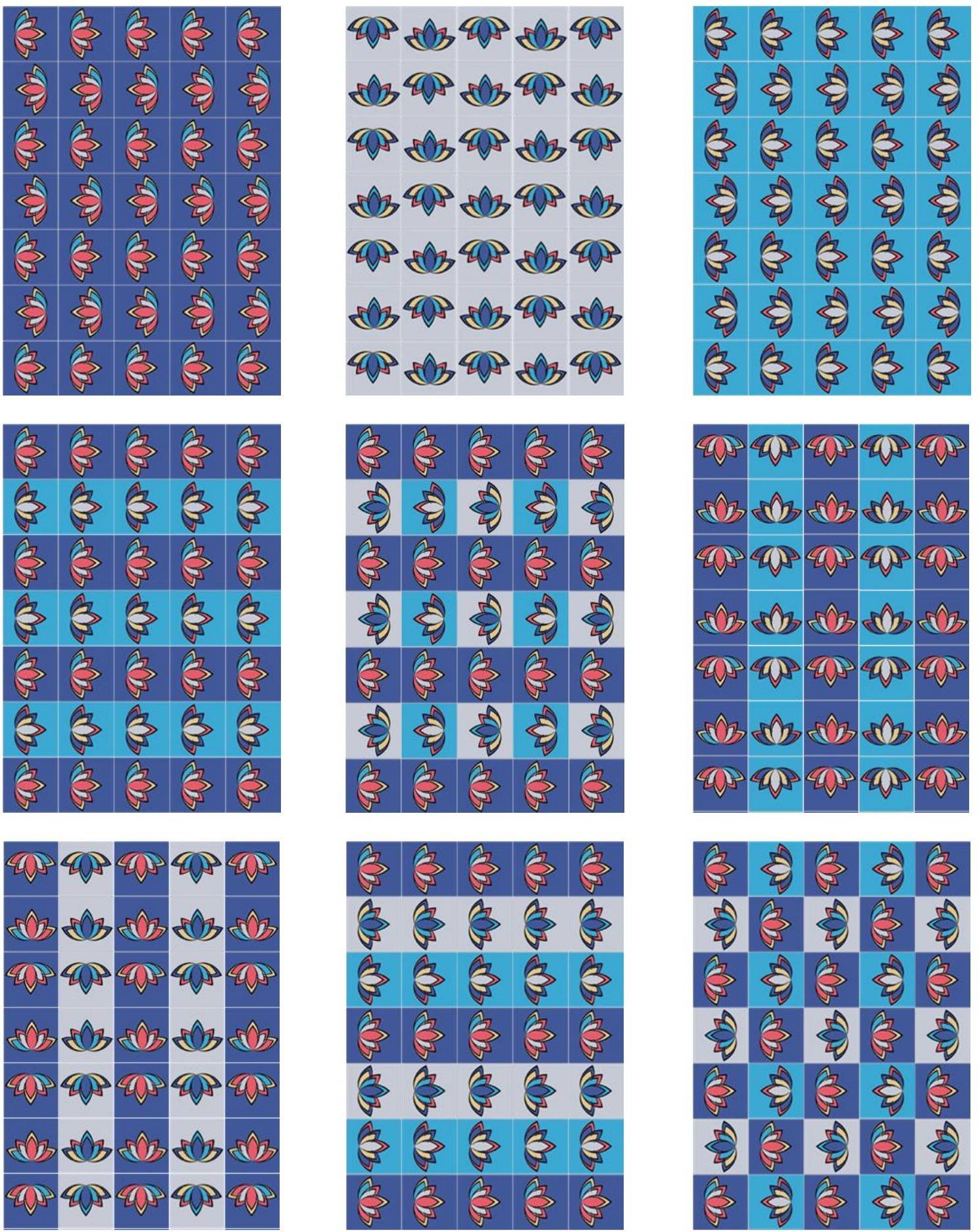

Figure 10. Projects of prints with stylized lotus 4

IRTIIE Vol. 4, No. 2, 2016 ISSN 1314-8788 (print), ISSN 1314-8796 (online), doi: 10.15547/artte.2016.02.002 


\section{IRTITE Ipplied Reseertrches in Technics, Technologies and Bducation Journal of the Faculty of Technics and Technologies, Trakia University https://sites.google.com/a/trakia-uni.bg/artte/}
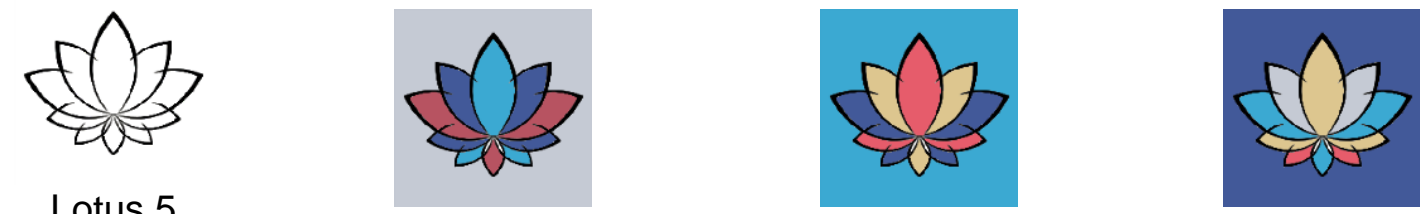

Lotus 5

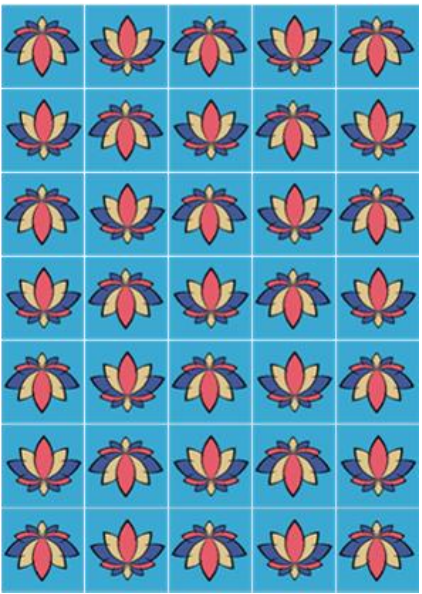
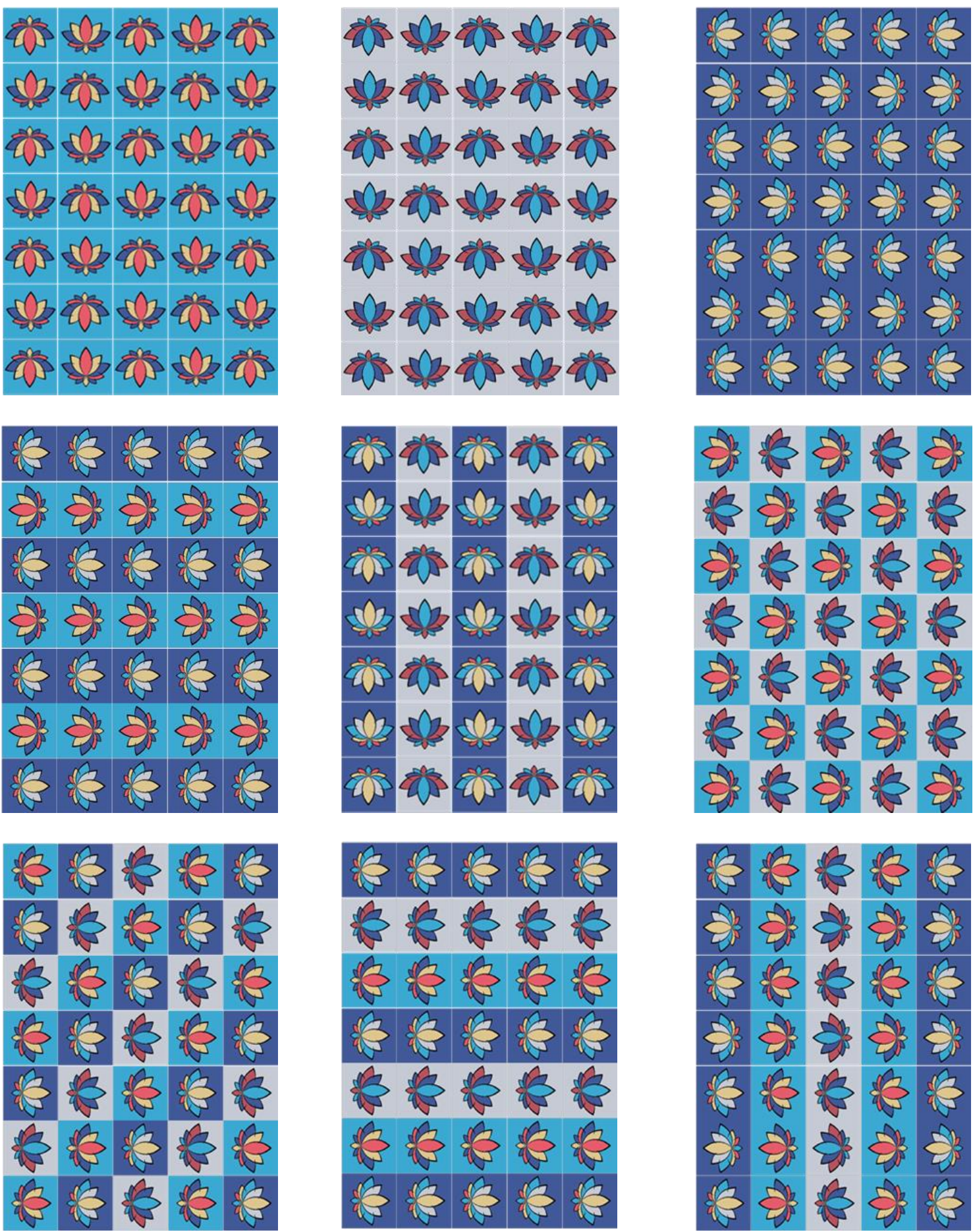

Figure 11. Projects of prints with stylized lotus 5

IRTTE Vol. 4, No. 2, 2016 ISSN 1314-8788 (print), ISSN 1314-8796 (online), doi: 10.15547/artte.2016.02.002 


\section{IRTTL $<>$}

Ipplied Researrches in Technics, Technologies and Educiation Journal of the Faculty of Technics and Technologies, Trakia University https://sites.google.com/a/trakia-uni.bg/artte/

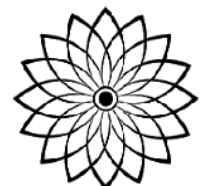

Lotus 6
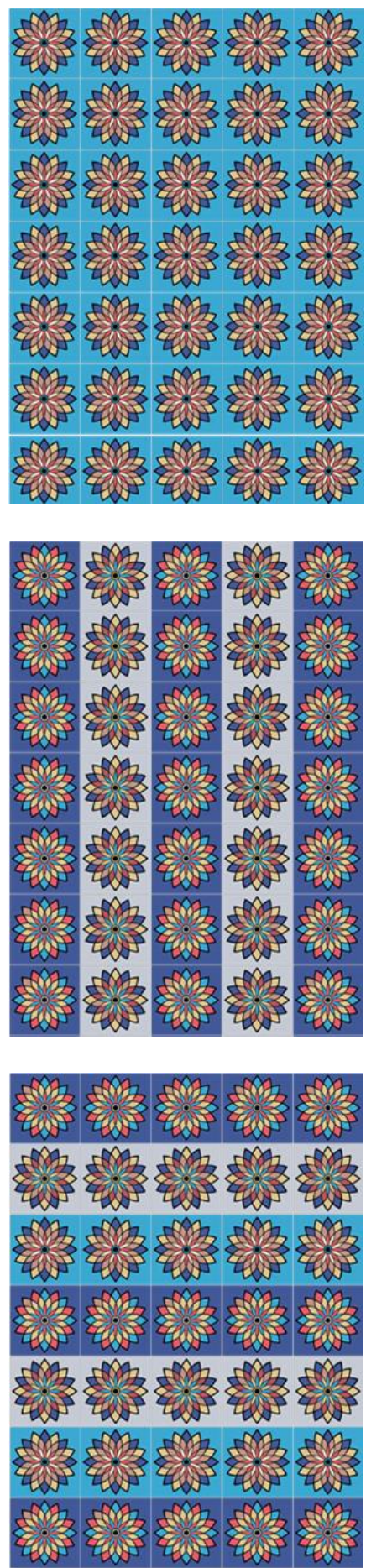
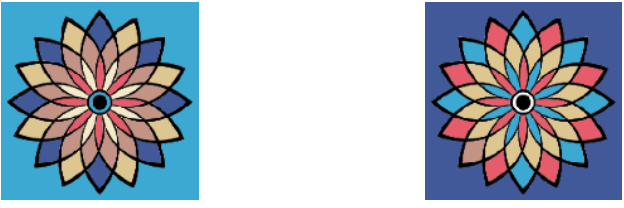
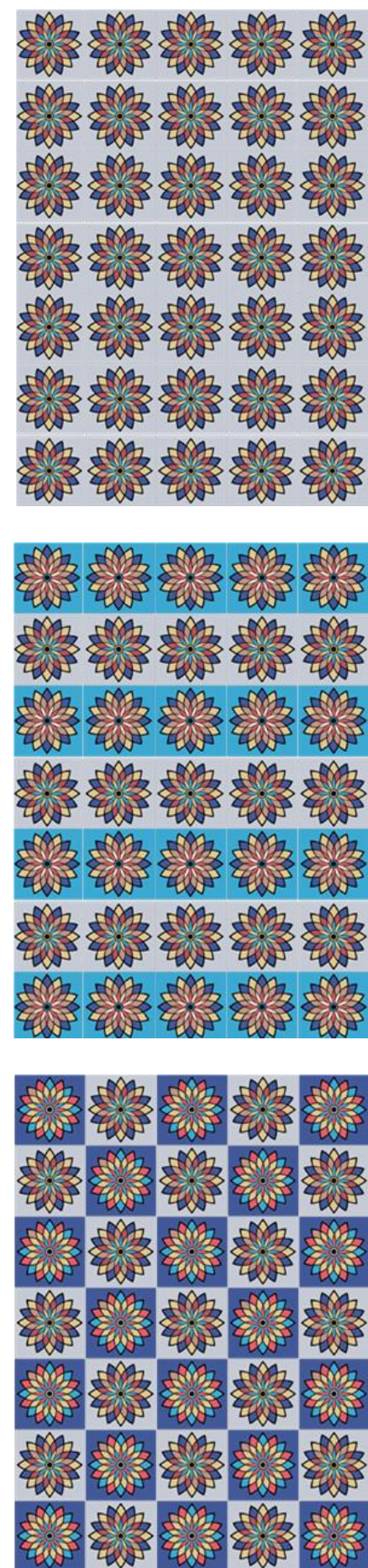
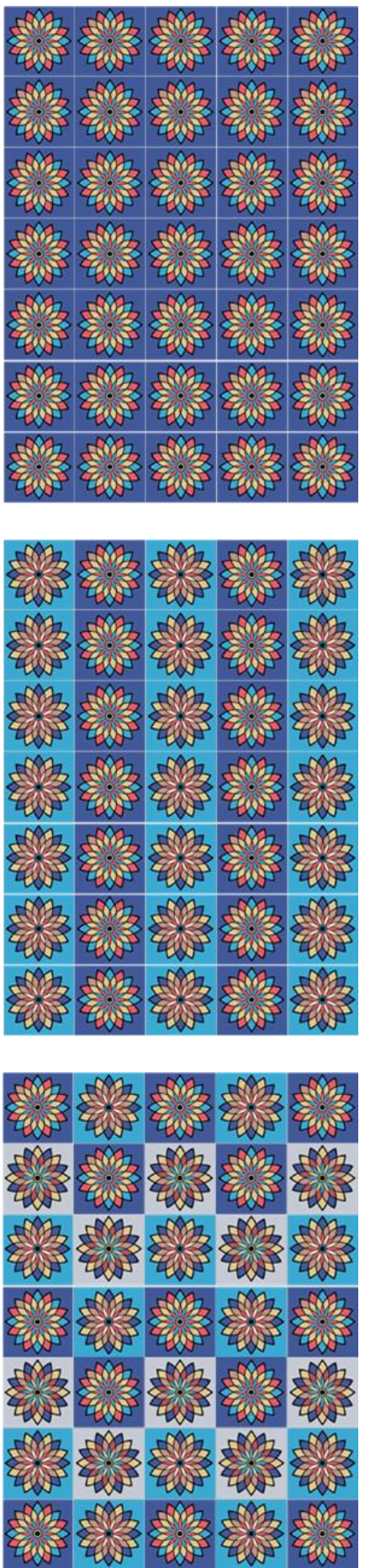

Figure 12. Projects of prints with stylized lotus 6

IRTIIE Vol. 4, No. 2, 2016 ISSN 1314-8788 (print), ISSN 1314-8796 (online), doi: 10.15547/artte.2016.02.002 


\section{ARTIIE \\ ( \\ Ipplied Reseirlches in Technicis, Technologies and Bductition \\ Journal of the Faculty of Technics and Technologies, Trakia University https://sites.google.com/a/trakia-uni.bg/artte/}

With the extracted 20 colors and 6 stylized ornaments with Lotus, are designed 104 textile prints and some of them -54 are presented in the above figures (Figures 7-12).

The digital collection of textile prints is organized on a website developed by tools of Google

Sites. This page presents the main results of the work. In this way they will be available to many people who have a connection to the Internet via mobile phones, tablets, PCs and mobile computers, televisions and "smart" devices as well as the „Internet of Things“.

In the main page of the site is a presentation of the author Julieta llieva and a brief summary of the projects.

The next sub-page are presented textile design with Fibonacci Rose and quadrangular star. Made is a brief description of these figures and video is presented for the preparation of the relevant geometries. These projects can be viewed and downloaded in *.PDF file format. This way of presenting the geometries and design of their base textile prints was used in other pages of the site.

Available is sub-page with completed projects.

Developed is sitemap aimed at facilitating the user in navigation in the website.

\section{CONCLUSION}

The costume of ancient Egypt and its decorative elements inspired designers in the design of clothing and textiles. To preserve the authenticity of ornaments and colors of ancient Egypt and the use of decorative elements on clothing to create patterns, decoration of clothes, at contemporary stage are applied analytical techniques and image processing. The resulting colors, shapes and metadata for elements of ancient Egypt can be used to create a digital collection.

Developed are software tools for obtaining colors, contours and radius-vector functions of decorative elements of ancient Egyptian costume. Using these tools facilitates the development of modern decorative elements with CAD systems. The vectorisation of the decorative elements allows for their comparison with those of national clothing of other countries.

Proposed is the use of the software tools for extracting colors which have the advantage that can be obtained a greater number of colors in comparison with known solutions in this field.

Combined are forms of decorative elements of the ancient Egyptian costume and colors of textiles and on their basis are designed modern textile prints.

With the extracted colors and stylized ornaments with lotus, are designed textile prints. A digital collection of these textile prints is organized on a website.

The original Egyptian motives placed on decoration increase the beauty of the textile prints. When strong elements are balanced with additional slight external elements then the composition is further improved.

\section{REFERENCES}

[1] A Framework of Guidance for Building Good Digital Collections, 3rd edition December 2007, National Information Standards Organization (NISO), ISBN(10): 1-880124-74-2, ISBN(13): 978-1-880124-74-1.

[2] Dineva P., Z. Kazlacheva, Design of women wear with three-dimensional elements, XXIV International scientific conference "Management and quality" for young scientists, 2015, ISSN: 1314-4669.

[3] Hanna F. B. M., V. Kuzmichev, E. A. EINashar, Innovative of frescoes in Suzdal Kremlin cathedral for fashion trends by using CAD systems, ARTTE Vol.2, No.4, 2014, ISSN 1314-8796, pp.345-357.

IRTTIE Vol. 4, No. 2, 2016 ISSN 1314-8788 (print), ISSN 1314-8796 (online), doi: 10.15547/artte.2016.02.002 


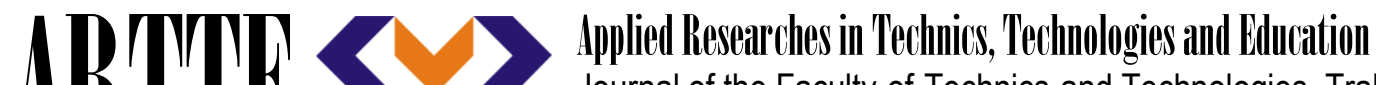 Journal of the Faculty of Technics and Technologies, Trakia University https://sites.google.com/a/trakia-uni.bg/artte/}

[4] Kazlacheva ZI., Optimum Use of Drawing Tools in CAD Systems in Automated Apparel Design, Trakia Journal of Sciences, Vol. 3, 2005, No 7, pp.20-23.

[5] Kertakova M. P., Conceptual dimensions of the historical costume of the nineteenth century and its implication in contemporary fashion, PhD thesis, Sofia, 2014 (in Bulgarian).

[6] Lotus design icon symbol, Vector illustration, http://ru.depositphotos.com/ (available on 02.05.2016).

[7] MathWorks Matlab, http://www.mathworks.com/ (available on 12.02.2016).

[8] Mladenov M., St. Penchev, M. Deyanov, Ts. Draganova, Application of contour models in seed sowing properties assessment using computer vision, Agricultural Engineering journal, vol.5, 2008, pp. 6-11, (in Bulgarian).

[9] Ornament of geometric shapes, http://sportfit.info/bg/pages/60014 (available on 07.04.2016).

[10] The sacred lotus flower, http://azor.blog.bg/hobi/2008/03/03/sveshtenoto-cvetelotos.169412 (available on 07.04.2016).

[11] Zlatev Z., G. Dolaphieva, Processing and analysis of images of folk costume from southeastern Thrace, Journal Textile and apparel, 2016 (in Bulgarian), (in press).

[12] Zlatev Z., J. Ilieva, Design of textile patterns by using colors from the Bulgarian national costumes, ARTTE Vol. 3, No. 4, 2015, ISSN 1314-8796, pp.309-316.

IRTIIE Vol. 4, No. 2, 2016 ISSN 1314-8788 (print), ISSN 1314-8796 (online), doi: 10.15547/artte.2016.02.002 